\title{
Falta embasamento científico no tratamento dos traumas mamilares
}

\author{
Lack of scientific evidence for the treatment of nipple traumas
}

\author{
Elsa Regina Justo Giugliani*
}

\begin{abstract}
A espécie humana evoluiu amamentando geração após geração. E se o aleitamento materno não fosse um ato prazeroso, provavelmente a espécie não teria sobrevivido. No entanto, traumas mamilares, que são muito dolorosos, têm sido um problema comum durante a amamentação há pelo menos 50 anos. Apesar disso, e, sendo uma importante causa de desmame, é surpreendente a escassez de estudos sobre o manejo clínico das lesões mamilares.

Muitos tratamentos têm sido utilizados ou recomendados para fissuras mamilares. Entretanto, a eficácia dos mesmos não tem sido avaliada adequadamente e, como conseqüência, os tratamentos de traumas mamilares utilizados rotineiramente não são embasados em evidências científicas.

As diferentes condutas descritas na literatura para o manejo do trauma mamilar podem ser agrupadas em três categorias: medidas de proteção, tratamento seco e tratamento úmido ${ }^{1}$.

As medidas de proteção visam minimizar o estímulo aos receptores da dor localizados na derme do mamilo e da aréola. Alternar diferentes posições de mamadas é uma dessas medidas, reduzindo a pressão nos pontos dolorosos ou tecidos danificados. Outra medida é o uso de "conchas" protetoras (alternativamente pode-se utilizar um coador de plástico pequeno, sem o cabo) entre as mamadas, eliminando a fricção da área traumatizada com a roupa. Esse dispositivo, no entanto, favorece a drenagem espontânea de leite, o que torna o tecido mais vulnerável a macerações. O uso das conchas, portanto, deve ser avaliado em cada caso, pesando-se os riscos e os benefícios. Já os protetores de mamilo devem ser evitados no manejo da dor ao amamentar, já que o seu uso pode exacerbar lesões pré-existentes ou mesmo ser a causa de trauma mamilar.
\end{abstract}

\footnotetext{
Professora de Pediatria da Faculdade de Medicina da Universidade Federal do Rio Grande do Sul. Especialista em Aleitamento Materno pelo IBLCE. Presidente do Departamento Científico de Aleitamento Materno da SBP.
}

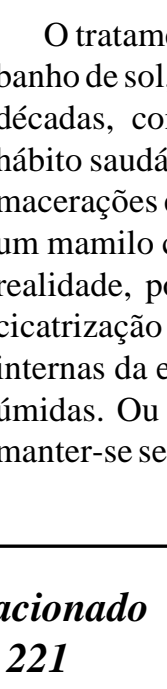

do das fissuras. O objetivo é formar uma camada protetora que evite a desidratação das camadas mais profundas da epiderme.

Embora não haja estudos respaldando o uso do leite materno ordenhado após as mamadas no tratamento das fissuras, essa conduta tem sido recomendada por experts, devido às propriedades antiinfecciosas do leite materno, $\mathrm{o}$ que, pelo menos em teoria, ajudaria a prevenir uma importante complicação das fissuras, que é a mastite. Têm sido utilizados, também, inúmeros cremes, óleos e loções, mas não há estudos que comprovem a sua eficácia. Alguns cremes são feitos à base de vitamina $\mathrm{E}$, mas há pelo menos um relato de que o uso tópico dessa vitamina nos mamilos poderia ser tóxico ao bebê ${ }^{2}$. O mesmo não ocorre com os cremes à base de vitamina $\mathrm{A} e \mathrm{D}$, que poderiam ser usados sem a necessidade de serem removidos antes das mamadas $^{3}$. Nos Estados Unidos, tem sido utilizada a lanolina anidra modificada, embora sejam limitados os estudos sobre a sua eficácia. Cremes ou pomadas com corticóide têm sido recomendados por experts, que relatam bons resultados no tratamento de fissuras, desde que afastada infecção por fungos ou bactérias ${ }^{1,3}$. Os corticóides citados na literatura são mometasona $0,1 \%$ (hidrocorticóide sintético) e propionato de halobetasol, que, segundo os experts, não precisam ser removidos antes das mamadas. 
Uma prática bastante difundida em algumas regiões do Brasil é o uso de chá no tratamento das fissuras. Existem dois estudos que mostram que o uso de saquinhos de chá não se mostrou mais efetivo do que compressas com água morna $^{4,5}$. Essas, devido à vasodilatação, podem trazer algum conforto para a mãe com dor nos mamilos. $\mathrm{O}$ ácido tânico presente no chá pode, na realidade, causar dano aos mamilos.

Como as fissuras mamilares são muito comuns, dificultando sobremaneira a amamentação, existem muitas práticas populares que visam a aliviar o sofrimento materno. Uma delas é o uso da casca de banana. Este número do Jornal de Pediatria contém o resultado de uma pesquisa desenvolvida por Novak et al. ${ }^{6}$, no Instituto Fernandes Figueira, que alerta para a possibilidade de que tal tratamento seja prejudicial. Os autores mostraram que a casca de banana pode ser veículo de bactérias potencialmente causadoras de mastite. Embora a pesquisa não possa concluir que o uso da casca de banana seja realmente prejudicial, o artigo se destaca por estudar um tópico tão pouco explorado na literatura e por fazer refletir quanto aos possíveis efeitos adversos do uso de remédios caseiros, não testados quanto à sua eficácia e inocuidade. Embora o ideal seja que as fissuras mamilares sejam prevenidas ao desencorajar algumas práticas (esfregar o mamilo vigorosamente no prénatal, uso de protetores de mamilo, uso de sabão, álcool ou outros agentes secantes) e encorajar outras (técnica correta da amamentação, banhos de sol e secagem dos mamilos íntegros ao ar livre e aleitamento materno sob livre demanda) ${ }^{1}$, não seria realístico imaginar que o problema deixasse de existir em curto prazo. São necessários estudos nesta área que ampliem os conhecimentos para que possamos manejar melhor e com mais segurança os traumas mamilares, desta maneira, aliviando o sofrimento materno e contribuindo para uma amamentação bem-sucedida. Que o estudo publicado neste número sirva de motivação para os autores e outros grupos de pesquisadores para a realização de novas pesquisas no manejo do trauma mamilar.

\section{Referências bibliográficas}

1. Biancuzzo M. Sore nipples: prevention and problem solving. Herndon: WMC Worldwide Publishing; 2000.

2. Marx CM, Izquierdo A, Driscoll JW, Murray MA, Epstein ME. Vitamin $\mathrm{E}$ concentrations in serum of newborn infants after topical use of vitamin E by nursing mothers. Am J Obstet Gynecol 1985; 152:668-70.

3. Lawrence RA, Lawrence RM. Breastfeeding: a guide for the medical profession. $5^{\mathrm{a}}$ ed. St. Louis: Mosby; 1999.

4. Buchko BL, Pugh LC, Bishop BA, Cochran JF, Smith LR, Lerew DJ. Comfort measures in breastfeeding, primiparous women. $\mathrm{J}$ Obstet Gynecol Neonatal Nurs 1994;23:46-52.

5. Lavergne NA. Does application of tea bags to sore nipples while breastfeeding provide effective relief? J Obstet Gynecol Neonatal Nurs 1997;26:53-8.

6. Novak FR, Almeida JAG, Silva RS. Casca de banana: uma possível fonte de infecção no tratamento de fissuras mamilares. J Pediatr (Rio J) 2003;79:221-6. 